\title{
Re-examining Burial Disputes in Kenyan Courts through the Lenses of Legal Pluralism
}

Ngira, D.O., 2018. Re-examining Burial Disputes in Kenyan Courts through the Lenses of Legal Pluralism. Oñati Socio-legal Series [online], 8 (7). Received: 06-08-2017; Accepted: 19-04-2018. Available from: https://doi.org/10.35295/osls.iisl/0000-00000000-0982

\begin{abstract}
This paper starts by exploring the place of customary law in socio-legal studies. It examines the different criticisms levelled against customary law and argues that although customary law is considered not to have the features of formal legal systems, the said comparison is unjustified as customary law and formal state law originate from different foundations. The second part of this paper highlights the contemporary theoretical discourse on legal pluralism. It responds to scholarly criticism of legal pluralism and traces the historical development of the concept. Using landmark burial disputes in Kenya, the paper examines the use of customary law in Kenyan courts. It identifies the inconsistencies and absurdities that result from the use of common law principles in the resolution of customary law disputes and advocates for the government to embrace non-state justice systems in resolving burial disputes.
\end{abstract}

\section{Key words}

Legal pluralism; customary law; burial disputes; legal proximity

\section{Resumen}

El artículo comienza por explorar el lugar del derecho consuetudinario en los estudios socio-jurídicos. Examina las diferentes críticas realizadas sobre el derecho consuetudinario y aduce que, a pesar de que no se lo considera dotado de las características de los sistemas jurídicos formales, la comparación es injustificada, porque el derecho consuetudinario y el derecho estatal formal tienen un origen distinto. La segunda parte del artículo se ocupa del discurso teórico actual sobre el pluralismo jurídico. Responde a las críticas académicas al pluralismo jurídico y busca el origen histórico del concepto. Utilizando las disputas sobre enterramientos en Kenia, se examina la aplicación del derecho consuetudinario en los juzgados de Kenia; identifica las inconsistencias que resultan del uso de principios del derecho común (Common law) en la resolución de disputas de derecho consuetudinario, y aboga por que el gobierno acepte sistemas no estatales de justicia para resolver las disputas por enterramientos.

\footnotetext{
* PhD Candidate, Utrecht University and a former Commonwealth Scholar at Warwick University. My research interest lies in human rights, jurisprudence and socio-legal studies. I highly appreciate the various thematic discussions that I held with Prof Barbara Oomen from Utrecht University during the writing of this paper. My email address is: otienongira@gmail.com. ORCID: https://orcid.org/0000-0001-9904-0819
}

\section{(c)) EY-NC-ND}

Oñati International Institute for the Sociology of Law Antigua Universidad s/n - Apdo.28 20560 Oñati - Gipuzkoa - Spain 


\section{Palabras clave}

Pluralismo jurídico; derecho consuetudinario; disputas por enterramiento; proximidad jurídica 


\section{Table of contents / Í ndice}

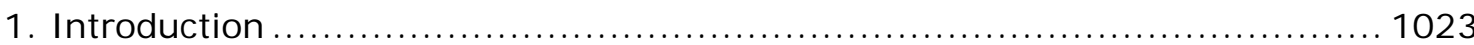

2. Customary Law and informal justice systems in Kenya ....................... 1024

2.1. Customary law and legal pluralism .................................. 1026

3. Customary law as a source of law in in state courts.......................... 1027

3.1. Resolving burial disputes through Kenyan courts................... 1028

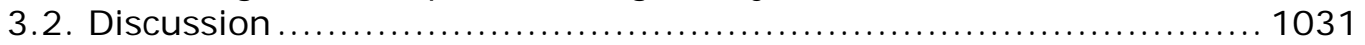

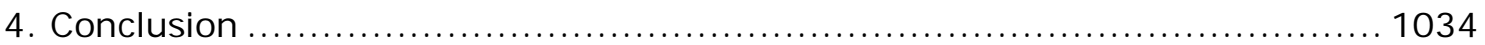

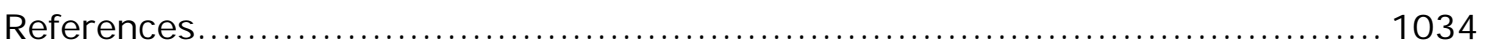

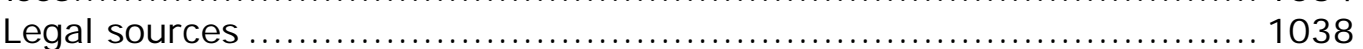

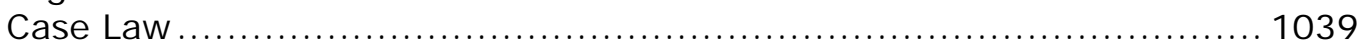




\section{I ntroduction}

While the question of treatment of dead people in general is an issue of culture and varies from place to place, anthropologists like Michael Brennan $(2008,14,21)$ argue that there is a general consensus on the significance attached to the dead by the living across various societies all over the world. It is generally noted that across ages, all societies have means of according respect to the dead, with some individuals even planning for their own burial ceremonies while still alive (Young and Cullen 1996, 2).

World over, different practices exist to celebrate the dead. These include visiting graveyards, marking minutes of silence to celebrate the dead, erecting monuments and periodically visiting the monuments, death anniversaries and elaborate funeral ceremonies (J upp and Gittings 2000, 256). Scholars such as Kwame Gyekye (1996, 419) have observed that the African way of existence goes beyond death; that death is a form of transformation to the after-life and therefore part of human existence. In most African societies, death ceremonies are often very elaborate and demonstrate the love of the living towards the dead person and his/her relatives.

Within this context, the means and place of interring the dead body has become an issue of legal contest, both within the formal and informal dispute resolution systems in Kenya (Abdullahi 1999). The contention over the place of burial has been problematic not only due to its effect on succession but also due to its implication on the social status of the dead person's surviving relatives. In Kenya, these disputes have been characterised by two main schools of thought: On one hand there are those who strongly believe in customary law. This group has always insisted that a dead person can only be buried on the family ancestral land and in a manner that is consistent with customary law (Kariuki and Kariuki 2015,6). On the other hand lies another group that sees no value in a dead body and argue that the burial of the dead can take place anywhere (Kuzenski 1924). To this end, they allow for cremation as well as burial in public cemeteries or in alternative pieces of land away from ancestral land. Disputes between parties from the two schools of thought over the burial of their dead relatives and partners are increasingly finding their way into the courts.

Although scholars have increasingly pointed out that common law is largely inadequate in resolving these cases (Nwabueze 2008) the courts have always fumbled with the disputes and provided highly contested solutions. To this end, numerous voices have emerged in Kenya calling for enactment of an act of parliament that would guide both burial processes and burial disputes (Abdullahi 1999, Mwendwa 2017). These calls, which are at least two decades old, have however failed to elicit any response or action from the state. This is possibly because the state is unwilling to navigate the complicated ethnic, clan and religious contest that such a statute would generate. The multiplicity of customary laws on burial, coupled with the emotive nature of deaths and the uneven influence of western lifestyles on rural and urban citizens has made such an endeavour fruitless. For instance, although written (or even oral) wills on places of burial are taken seriously by most city dwellers, people who live in the villages largely ignore them if they consider them to be inconsistent with customary law. In the absence of any statute on this matter, courts have been compelled to fall back to and (re) interpret customary law in dealing with burial disputes.

Using six landmark cases, ${ }^{1}$ this paper explores the (in)adequacy of state courts in handling these disputes and the extent to which informal justice systems can be strengthened to handle burial disputes. Such an approach can not only fill the gap

\footnotetext{
${ }^{1}$ These are: Virginia Edith Wambui Otieno v Ochieng Ougo \& Anor [1987], Ruth Wanjiru Njoroge v Njeri Njoroge \& Anor [2004], Martha Wanjiru Kimata \& Anor v Wanjiru \& Anor [2015], Eunice Moraa Mabeche $\&$ Anor v Grace Akinyi (1994), Pauline Ndete Kinyota Maingi v Kinyota Maingi (1984) and Edwin Otieno Ombajo v Odera Okumu [1996].
} 
left by the lack of express statutory provision on burial disputes (that has resulted into inconsistent legal outcomes) but will also provide a clear framework on how burial disputes are can be effectively resolved.

\section{Customary law and informal justice systems in Kenya}

The definition of "informal justice system" is largely elusive. Some scholars consider them as customary justice systems, others view them as traditional justice systems and others as non-formal justice systems ( $F$. Kariuki 2015a, 2015b). Other terms commonly used to refer to these justice systems include "popular justice systems" and "non-state justice systems" (Musembi 2003). This study will consider informal justice system to be a justice system that may or may not fully derive its authority from the state but whose mode and procedure of dispute resolution is not guided by formal rules or statutes and are not part of the judicial system. This definition also encompasses traditional justice resolution processes that are partly recognised by the state. Thus although traditional justice systems are recognised by article 159 of the Kenyan Constitution (2010), they fall within the framework of informal justice systems and will be the focus of this paper. This is because the state neither regulates their activities nor considers them as part of the legal systems (Ibid.). Courts therefore have original jurisdiction on all matters that have previously been determined by the informal justice systems.

Winfred Kamau defines "customary law" as unwritten norms and practices of small scale communities which date back from pre-colonial times but which have undergone transformation due to colonialism and capitalism (Kamau 2015, 141). Discourse on customary law has been characterised by different (and sometimes antagonistic) approaches. On one hand, there are scholars who argue that what is currently considered as customary law is a colonial invention and that pre-colonial societies were governed through fluid notions of culture and not static customary law as we understand it today (Bennett 2009). To them, the phrase "customary law" resulted from the codification of customs that characterised European colonization (Mamdani 1996). They therefore see a difference between lived customary law, which is experienced in the daily lives of the people, and the documented customary law that is found in law books and statutes (Bennett 1991). However, some scholars do not see any difference between lived customary law and the codified customary law. To them, codification is a positive step towards making customary law more predictable and in line with modern legal systems, justice and human rights (Pimentel 2010). A third category of scholars do not consider customary law to be law at all. They include the Fullerians, who see customary law as lacking Lon Fuller's eight requirements that a rule must meet before it is considered as law (Waldron 2008). According to Fuller, a law must be: officially promulgated, sufficiently general, set realistic standards, applied in a way that is consistent with its wording, applied prospectively, clear and unambiguous, free from any contradictions and not be subject to arbitrary changes (Fuller 1964). To this end, Fuller (1969) argues that customary law should either be considered as a form of interactional expectancies or as a language of interaction but certainly not as law. Fuller and Fullerians have however been criticised for subjecting customary law to a strict test of internal morality of law, while ignoring the fact that most formal laws and legal systems do not meet these requirements (Pavone 2014). For instance, in a bid to comply with the requirements of the standards of the World Anti-doping Agency and United Nations Scientific and Cultural Organization (UNESCO) Convention against Doping in Sports, the Kenyan parliament enacted the Anti-Doping Act in April (2016). However, in June of the same year, the same Act was amended through the Anti-Doping Amendment Act (2016). Although the anti-doping legislation fails Fuller's test of legal stability and infrequent change due to the fact that it was amended only after two months, Fullerians would easily recognize it as a valid law. Thus, the failure of the Anti-Doping law to meet Fuller's tests of internal morality neither negates its identity as a valid law in Kenya nor compromises the quality of Kenyan legal system. 
Although Fuller did not absolutely reject the value, origin, nature and role of customary law in society, he doubted whether customary law meets the test of law. Fuller wonders:

(...) the phenomenon called 'customary law' can best be described as a language of interaction. To interact meaningfully men require a social setting in which the moves of the participating players will fall generally within some predictable pattern. To engage in effective social behaviour men need the support of intermeshing anticipations that will let them know what their opposite numbers will do, or that will at least enable them to gauge the general scope of the repertory from which responses to their actions will be drawn. (Fuller 1969, 2)

Fuller has further argued that customary law fails the test of law because it is anchored upon regularity and habitual practices of a particular society. In other words, the justification for the implementation and enforcement of customary law neither lies in its moral content nor on its source but is rather derived from its repetitiveness (Fuller 1969,8 ). This, it has been argued, fails to provide a proper justification for the consideration of customary law as law. However, scholars like J ef De Mot and Francesco Parisi have argued that customary law, unlike other forms of law reflect direct legislation through action (De Mot and Parisi 2014). Accordingly, they point out that customary law is justified due to the fact that it is composed of a quantitative element consisting of a general practice and a qualitative element reflected in the belief that the practice reflects a legal obligation. Other scholars have observed that because "customary law" is a blanket term used to refer generally to indigenous law without any distinction of the ethnic community, the term should be used sparingly to avoid conceptual confusion (Chanock 1989, Mamdani 1996). Since each community has its own customary legal systems, the recognition of customary law as a form of law must start by identifying the distinctive features and customs of each community (Ndulo 2011, 88).

The recognition of customary law as a form of law has also attracted scholarly criticism from Michaels who has pointed out that neither customary law nor any form of non-state social order can be considered as law because they require the state to approve them as law (Michaels 2005). Accordingly he insists that the extent to which non-state legal systems would meet the test of law largely depend on the extent to which the state considers them as law. Ellickson (2005) and An-Na'im (1992), on the other hand, have argued that state law itself can be ineffective if not grounded in the living law. In other words, people are likely to respects aspects of state law that are grounded in their norms and values. To this end, stakeholders must directly engage communities in cross-cultural dialogue with the view of demonstrating the extent to which the state law or policy in question borrows from or reflects prevailing cultural norms (An-Na'im 2010, 28). According to An-Na'im, such an approach may be needed to promote a cultural acceptance of human rights. Similarly, scholars like Muigua Kariuki and Francis Kariuki (Kariuki and Kariuki 2015, 12, M. Kariuki 2015) and Busalile Mwimali $(2015,10)$ have observed that customary law is sometimes preferred over state law not only because it is cheap and efficient but also because grassroot communities generally associate more with "indigenous justice" that is meted by customary institutions than the imported forms of justice associated with state law.

It has also been pointed out that customary law and state law originate from different foundations and that the yardsticks and principles of one legal system cannot be used to judge another legal system (Ndulo 2011). To this end, both the yardsticks set by legal moralists like Fuller, positivists like Herbert L.A. Hart (1961) and centralists like Ralph Michaels (2005) are inapplicable to customary law because their conception of law is not only western but also statutory. As pointed out by Eugene Erhlich and J ohn Griffiths, law can exist outside the domain of the state and the state neither has monopoly of its implementation nor its source (Ehrlich and Isaacs 1922, Griffiths 1986). Rather each society has its own unique form of normative ordering complete with an enforcement mechanism. 


\subsection{Customary law and legal pluralism}

Discourse on the extent to which customary law should be considered as law has been associated with age old debate on legal pluralism. By definition, legal pluralism refers to a situation in which two or more distinct legal systems co-exist within the same political community (Griffiths 1986). Within this context, the presence of international law, national laws, customary law and county laws (as is the case in Kenya) would suffice to be considered as legal pluralism (Oomen 2014). The lives of grassroots community members are therefore shaped and influenced by international human rights law (which is itself shaped by the claims and counter claims of grassroots community members), by state law and by customary law (I bid., 475). Building on this broad conception of "legal pluralism", Oomen (Ibid.) notes that contrary to widely held perceptions, legal pluralism exists both at national and international level. Although the concept of "legal pluralism" first came into sociolegal studies through the works of John Griffiths and Eugene Erhlich, the practice of legal pluralism can be traced to many conquered territories throughout human history where conquering powers allowed locals to practice their own laws (Tamanaha 2008). For instance upon conquering the Middle East, the Romans allowed the Jews to continue practising Jewish law for as long as it wasn't in conflict with official Roman Law. The same applied to the Ottoman Empire where Christians and Jews were allowed to retain their faith for as long as they consented to Ottoman rule (I bid.).

Legal Pluralism, just like all other theories of law has very sharp critics. Letsas notes that coexistence of state law and customary law (that he calls "normative systems") leads to incidents of social tension, conflict and confusion (Letsas 2012). Other scholars like Woodman and Jackson have also criticized "legal pluralism" for equating all forms of social control to the law, noting that it amounts to trivialization of the law and may even problematize the realization of justice (Woodman 1996, 158, Jackson 2006, 160). Highlighting the jurisprudential problem paused by legal pluralism, Letsas poses:

(...) the existence of legal pluralism can make trouble not only for the society that exhibits it, but also for mainstream jurisprudence. Most theories in mainstream analytic jurisprudence were developed to capture features that only state-ordained normative systems possess - such as sovereignty (Bentham and Austin), the vertical, 'top-down' structure of a legal system (Kelsen), the existence of secondary rules unifying all legal norms (Hart), state coercion (Dworkin) (...) for pluralists these theories are ill-suited to capture these other normative practices that lack some or all of these. (Letsas 2012)

Tamanaha (2008), on the other hand, argues that the problem with legal pluralism is not necessary a problem of whether non-state law should be considered as law, but a question of lack of unity in defining what the law is. To him, critics of legal pluralism have a narrow conception of the law which disregards its socio-cultural foundations. Sally Moore (1973), in her anthropological study in Tanzania, has demonstrated how some social systems, which she calls "semi-autonomous social field", are impermeable to state law. According to her, the external dynamics of traditional communities in developing countries are regulated by state law but the direct social interaction of people within these communities is only subject to nonstate normative ordering. Similarly, Stephanie Lagoutte has observed that whereas state law on divorce exists in Africa, the entire enterprise of marriage is largely subject to non-state normative ordering that is not only impervious but also resistant to state intervention (Lagoutte 2014). She opines that any attempt to promote women's rights within marriages must start with an appreciation of the non-state normative orders onto which marriages and families are founded. Janine Ubink (2011), in a Namibian study, Julie Davies and Dominic Dagbanja (2009) in a Ghanaian Study, and Tanja Chopra and Deborah Isser (2011) in a Somali study have all agreed that non-state justice systems that largely rely on customary law to resolve disputes are still very prevalent in most parts of Africa. They operate outside the domain of the state but handle disputes that would conventionally be addressed by 
state justice systems in western societies. To this end, rule of law initiatives in Africa must therefore incorporate these institutions if they are to reach the poor and vulnerable (Ubink and van Rooij 2011).

The extent to which customary law can validly be considered as law has elicited an ongoing debate that is not likely to end soon. This paper is therefore based on the firm recognition that customary law is a living form of law that predominantly regulates communities in non- western societies. The Judicature Act (1967), Constitution (2010), Land Act (2012), Matrimonial Property Act (2013) and Marriage Act (2014), although not giving much detail on its application, recognize customary law as a form of law in Kenya. In the absence of any statute dealing with burials, courts have had to almost exclusively rely on customary law to resolve burial disputes. The next section explores the extent to which Courts rely on customary law to resolve burial disputes and the inadequacy of common law in addressing burial disputes.

\section{Customary law as a source of law in in state courts}

The Judicature Act (1967) and Section 2 (4) of the Constitution (2010) expressly list customary law as a source of law in Kenya. The Judicature Act (1967) specifically says that:

The High Court, the Court of Appeal and all subordinate courts shall be guided by African customary law in civil cases in which one or more of the parties is subject to it or affected by it, so far as it is applicable and is not repugnant to justice and morality or inconsistent with any written law (...). [J udicature Act (1967), Section 3 (2)]

It is on this basis that courts often rely on customary law to resolve disputes including (but not limited to) matters of succession, land, matrimonial property, and marriage. The respective Acts of parliament: Succession Act (1981), National Land Commission Act (2011), Matrimonial Property Act (2013) and Marriage Act (2014). Customary law is also envisioned in the Children's Act [2001, article 76 3(g)]. However, jurisprudence in this respect is largely underdeveloped because courts generally interpret the doctrine of "best interest of the child" to be inconsistent with culture which has been erroneously and homogenously condemned as being inconsistent with children's rights.

It is noteworthy that debate on the use of customary law in state courts has not been on whether customary law is applicable or not. Rather, it has been on the interaction between customary law and state law in view of the repugnancy test. Thus although post-independence Parliaments have been fairly friendly to customary law, and have recently enacted the Community Lands Act (2016), which requires community land to be administered according to customary law, the lack of a clear framework on how courts should interpret customary law, coupled with the fluidity and dynamic nature of customary law continues to militate against its effectiveness resulting into unlimited discretion by courts. The absence of any express section on customary law in the Interpretation and General Provisions Act (1956), an act of parliament that guides courts in interpreting statutes and other legislations, perhaps demonstrates the attitude of the pre-independence parliament towards customary law. This historical marginalization of customary law institution has contributed to a state centric approach in which courts presume jurisdiction over all disputes, including the ones in which the states courts are ill equipped such as burial disputes. It is important to point out that due to the existence of express legislations on land, succession and matrimonial property, courts have to a great extent, demonstrated some consistency and efficiency in utilizing customary law in resolving disputes in this area. This is partly due to the fact that land matters are largely determinate and have 
comparatively less religious, sentimental and clan based superstitions and beliefs that characterise burial. ${ }^{2}$

\subsection{Resolving burial disputes through Kenyan courts}

Although courts have attempted to interpret customary law in resolving burial disputes, they focus on common law principles such as judicial precedence. Overreliance on codified customary law and their focus on the repugnancy test (which only recognizes customary law to the extent of its consistency with state law and morality), have compromised their ability to amicably resolve these disputes, resulting into protracted burial disputes that linger in the court (as well as in public domain) for a long time. To this end, jurisprudence in burial disputes have developed in four contradictory dimensions in the Kenyan Courts.

The first dimension is best reflected in Virginia Edith Wambui Otieno v Ochieng Ougo \& Anor [1987]. The plaintiff in this case, Virginia Wambui, was a member of the Kikuyu ethnic community who was married to Silvano Melea Otieno (hereafter "SM Otieno"), an Indian trained lawyer in Nairobi and a member of the Luo ethnic community. Upon Otieno's death, Wambui wanted to bury him in their matrimonial home in Nairobi. However, Otieno's clan, through Joash Ougo, went to court to stop the burial and have the body buried among his clan members in Nyanza-western Kenya. In her court submission, Virgina Wambui argued that SM Otieno had embraced "modernity" as well as European civilization and was therefore neither affected by nor bound by Luo customs. He didn't even build a simba. ${ }^{3}$ However, the Court of Appeal judges rejected her argument noting that:

... the decision as to where and how an adult Luo will be buried rests with the clan from which he hails. Even if a man may have, in his lifetime, expressed a wish as to his place of burial, it is in evidence that the wish will be subject to the customs and traditions of his clan. The clan sages are not, necessarily, bound to comply with those wishes if they do not conform to the customs and traditions of that clan (...).

The court therefore set precedent by giving the body to the clan for burial at his ancestral home in western Kenya. This precedence continued to impact on burial disputes in Kenya for a long time and was the ratio decidendi in Kandie \& 2 others $v$ Cherogony [2002] where the High Court ordered a woman to surrender her husband's body for burial to his Tugen ${ }^{4}$ clan based on customary law. The Judge pointed out that:

... the customary law of the Tugens is that a man must be buried by his father and family members at his ancestral home. In the case of the deceased herein, at Tiriodonin, Baringo District. It was never suggested that such a custom is inconsistent with any written law and in SM Otieno's case, the Court of Appeal held that it is not repugnant to justice or morality.

SM Otieno's case similarly informed the court decision in Salina Soote Rotich $v$ Cheptoo et al [2010] where the High Court revoked an earlier decision by a Magistrate Court allowing the daughter of the deceased to bury him in their family home located away from their ancestral land. The High Court, in upholding the principles in the SM Otieno case noted that an African, throughout his life and death, is bound by his customary law. It therefore revoked the decision of the Magistrate's Court and allowed Soote (deceased man's mother) to bury him in the ancestral land.

This principles of binding custom were however set aside by Justice Jacton Ojwang (then of the High Court) in Ruth Wanjiru Njoroge v Njeri Njoroge \& Anor [2004] (hereafter Njoroge case) where the second wife (Ruth Wanjiru) sought to stop the first wife and the mother-in-law from burying her husband in their ancestral land and

\footnotetext{
${ }^{2}$ Although the author admits some challenges in these areas, the same is outside the scope of this paper.

${ }^{3} \mathrm{~A}$ traditional house which a Luo man builds (and lives in) upon attaining adulthood.

${ }^{4}$ An ethnic community in Kenya.
} 
have him buried in their matrimonial home in Kajiado. ${ }^{5}$ Although Justice Ojwang allowed the deceased man to be buried in his ancestral land, he introduced a new doctrine in burial disputes; that of legal proximity. The doctrine of legal proximity is based on the assumption that the decision as to the determination of the place of burial is based upon proof by the parties in the dispute of their proximity to the deceased. Accordingly, the right to bury a dead body can only be conferred to the person who is able to demonstrate the closest proximity to the deceased. Ojwang noted that:

... in social context prevailing in this country, the person, who is in the first line of duty in relation to the burial of any deceased person, is the one who is closest to the deceased in legal terms. Generally the marital union will be found to be the focus of the closest chain of relationships touching on the deceased. And therefore, it is only natural that the one who can prove this fundamental proximity in law to the deceased, has the colour of right of burial, ahead of any other claimant.

This position was held in Martha Wanjiru Kimata \& Anor v Wanjiru \& Anor [2015] (hereafter Wanjiru case) where the court held that the wife was the closest in proximity to the husband, and therefore had the right to bury the deceased husband. A similar argument was held in John Omondi Oleng \& Anor v Radal (2012) (hereafter Omondi case) where the High Court emphasised that it was the responsibility of the surviving spouse to bury the dead spouse. In his judgement, the Court ruled that:

... when it comes to the disposal of the body of a married man or woman the spouse should play a leading role. It would be better if the relatives of the deceased can sit down and agree on how to give their loved one a dignified exit. When they fail to agree and approach the court for solution, the court has no option but to step in (...). There has to be somebody to bury a deceased person. In my view a surviving spouse is the person with the greatest responsibility for laying to rest the remains of the deceased spouse (...).

The third dimension is borrowed from the common law principle that the wishes of the deceased over his burial place should be paramount in determining his place of burial. This argument proceeds from the common law assumption that there is no property in a dead body. ${ }^{6}$ Accordingly they argue that customary law should only be considered in instances where a person dies intestate. This argument was the ratio decidendi in Eunice Moraa Mabeche \& Anor v Akinyi (1994) where the high court allowed the deceased's body to buried in a Muslim cemetery based on his wishes and rejected his mother's attempt to bury him in his Kisii ancestral home subject to Kisii customs. A similar position is reflected in Charles Onyango Oduke \& Anor v Onindo Wambi [2010] where the High Court held that "courts ought to give effect to the wishes of the deceased as far as possible".

Other judges have introduced nuances to this position and argued that the will of the deceased cannot be respected if it contravenes customary law. In other words, a petitioner in a burial dispute must demonstrate that the deceased's will doesn't violate the customary law of his community, otherwise customary law prevails. This view formed the ratio decidendi in Pauline Ndete Kinyota Maingi v Kinyota Maingi (1984) where the high court ruled that the wishes of the deceased over his burial place could not be respected as they violated Kamba customary law. The same argument was upheld in James Apeli and Enoka Olasi v Prisca Buluka (1979), where the court noted that

(...) the most important rule is that the wishes of the deceased person, though not binding, must so far as possible be given effect to (...). Where the wishes of the deceased are not contrary to custom nor the general law or public policy or safety, as it was in this case, the High Court has a general discretion to order the removal of the remains of the deceased from one place to another subject (...).

\footnotetext{
${ }^{5}$ Kajiado is a county that is located in the periphery of Nairobi city.

${ }^{6}$ For such a judgement, see Jacob Blasto Okumu et al v Auma [2014]. See also Dobson \& Dobson v N. Tyneside HA \& NCL HA [1997], William v William [1882].
} 
The last position, which perhaps demonstrates an attempt by courts to develop customary law (rather than interpret it), considers the relationship between the deceased and the litigants in burial disputes. Accordingly, it is argued that a person with whom the deceased had a sour relationship cannot be allowed to bury him/her regardless of the position of customary law. Judges who adopt this position have validated it on the basis that because it doesn't expressly contradict morality and justice it is acceptable under customary law. In other words the mistreatment of the deceased (while still alive) by a litigant negates his/her customary rights to bury $\mathrm{him} / \mathrm{her}$. This argument formed the ratio decidendi in Edwin Otieno Ombajo v Odera Okumu [1996] where the Court of Appeal pointed out that :

We wish to observe here that customary law, like all other law, is dynamic. Because it is not codified, its application is left to the good sense of the judge or judges who are called upon to apply it. That is why, as its stated earlier S. 3(2), above, is worded the way it is to allow for the consideration of individual circumstances of each case. So the conduct of the respondent and his attitude towards the deceased generally, were important considerations in determining the dispute between the parties here.

The question as to whether state courts can develop customary law has been subject to an intense scholarly discourse with scholars such as Bennet opining that customary law should be developed as a form of African equity (Bennett 2011) while others arguing that the nature of legal training of most judges and magistrates makes it likes likely that they will have a positive attitude towards the development of customary law (Ojwang 2015). To these scholars, judges only fall back to customary law when they run out of legalistic principles and statutes. This argument is not necessarily farfetched. Justices Duffus in Kimani v Gikanga [1965], Ruth Sitati in Frank Angatia v Lubembe [2016] and Asike Makhandia in Nyariba Nyankomba v Munge (2010) have all admitted that judges are not experts in customary law (and therefore need the assistant of elders and other experts in interpreting it). Makhandia notes that:

Time and again it has been stated that in cases resting purely on customary law it is absolutely necessary that experts versed in the customs be summoned to testify so as to assist the court reach a fair verdict since the court itself is not well versed in those customs and traditions (...). [Nyariba Nyankomba v Munge (2010)]

J ustice Lydia Achode in concurring with the above sentiment has recently noted that unlike other cases, affidavit evidence cannot be relied upon in determination of matters of customary law unless the same is corroborated by expert evidence. In overturning a magistrates court decision that relied on affidavit evidence to prove the existence of customary law of marriage Achode held that:

\begin{abstract}
...the affidavit evidence filed by the parties herein was not sufficient for the trial court to have a proper appreciation of the customary law relating to the specific marriage. There was need for expert evidence to be called to that effect, for the court to effectively interrogate the issues of customary law marriage and determine that the relationship amounts to a legally constituted Luo Customary marriage, or that there was dissolution of the said marriage between the parties thereto. The determination of these two issues is too complex and varied from community to community be left to affidavit evidence. (CBG v JLW [2017])
\end{abstract}

It is such admission by judges that provides credit to the position advanced by this paper that informal just systems should be strengthened to preside over matters of customary law as they possess the expertise to critically engage with customary matters. It is noteworthy that even when courts talk of experts, they often mean community elders or in some cases, anthropologists who possess the requisite training in the customs of the specific community in question. Instead of having parties avoid the informal justice systems only for their matters to end up being determined on the basis of expert evidence given by the same elders, litigants should be encouraged to exhaust the informal justice options in burial disputes before opting to go to court. 


\subsection{Discussion}

The contestation over the exact role of customary law in burial disputes has continued to bedevil the Kenyan legal system to date. Part of the problem is that whereas formal legal systems are largely gapless systems that exclusively rely on statutes and precedents to resolve disputes, there exists no statute in Kenya on burial disputes. The Judicature Act (1967) that has been extensively cited in these cases is extremely limited as it simply classifies customary law as a form of law without stating the extent of its use (J udicature Act 1967, section 3). At the same time, the repugnancy clause in the Judicature Act (1967), and the Constitution, which only allow the use of customary law "to the extent that it is consistent with morality and written law", has led to uncertainty in judicial interpretation of customary law [J udicature Act 1967, section 3(2); see also Constitution of Kenya]. This is because the term "morality" is largely ambiguous and in the absence of an authoritative definition or source of morality, judges have either resorted to common law conceptions of morality (which generally considers African customs to be immoral; see, for instance, Maria Gisege Angoi v Nyomenda (1981), see also Katet Nchoe \& Anor v R [2011]) ${ }^{7}$ or avoided defining it altogether. Other Common Law jurisdictions such as South Africa have altogether outlawed the repugnancy test and argued that customary law, just like statutes, can only be subject to constitutional test and not a moral test; see, for instance, Alexkor \& Anor v Richtersveld [2003].

The absence of a constitutional and a statutory provision on burial has left courts with no option other than to grapple with customary law. To this end, courts have partly relied on restated customary law to handle burial disputes. Restatement of customary law is basically the documentation and codification of all the customs of a community (Chanock 1989, 9). In Kenya, the most widely used texts in this respect are Restatement Of Customary Law and Casebook On Customary Law by Eugene Cotran, publications that were informed by the colonial and postcolonial government's attempts to regularize and order customary law. Codification of customary law has however faced criticism from scholars who have dismissed it not only as a colonial enterprise but as a process that had robbed customary law of its integrity and compromised its development (Mbote 2002, 9, Ubink 2011, Kamau 2015). The use of restated customary law in the resolution of burial disputes has thus been criticised by disputants and scholars who have argued that they neither reflect the changing nature of customary law nor the actual living customary law as they are products of top-down colonial attempts at westernizing customary law (Abdullahi 1999).

Kenyan courts have also relied on the doctrine of judicial precedence to determine burial disputes. This doctrine requires that similar cases must be handled in the same way and largely employs reasoning by analogy (Levi 1948, Scharffs 2004). However, this doctrine is only suited for cases that mirror British legal systems (where common law traces its origin) such as administrative matters or commercial disputes that often do not have a customary orientation. This is because the ethnic diversity in Kenya has resulted into numerous burial customs each with a different and unique cultural foundation. ${ }^{8}$ Thus, whereas the facts of two burial dispute may be similar, the ethnic and religious background of the deceased and the disputants may result into different sets of customary laws that cannot be addressed through the doctrine of precedence. Any attempt at doing the same (as has been seen in the above cases) not only results into inconsistencies but also propagates injustice on the parties. For instance due to the doctrine of judicial precedence, the 1987 decision in the SM Otieno case, that was based on Luo ${ }^{9}$ customary law, continued to act as binding precedence even in burial disputes from communities whose customs were different from the Luo

\footnotetext{
${ }^{7}$ For similar positions in other common law jurisdictions in Africa, see a landmark Ugandan case, Mifumi \& Anor V AG \& Anor [2015] and Mojekwu et al v Ejikeme et al (2000), a widely cited case from Nigeria.

${ }^{8}$ Anthropological records indicate that Kenya has about 44 ethnic communities.

${ }^{9}$ An ethnic community in Kenya.
} 
customs of burial. The doctrine of legal proximity, which can be traced to the 2004 Njoroge case, has not been applied consistently by the courts as some judges have chosen to stick to the principle of "binding custom" established in the SM Otieno case. Still other judges have upheld the will of the deceased or considered the unique circumstances of the death and relationship between the deceased and the litigants in granting burial rights. The Courts position in SM Otieno - that burial on ancestral land is consistent with morality and justice- has however attracted a sharp criticism from feminist legal scholars who argue that it amounts to legitimizing discriminatory customary practices that militate against the rights of widows and the wishes of the dead (Nyamu 2000, 40).

Within the plural legal system that Kenyans find themselves in, the doctrine of legal proximity that has been hailed as a breakthrough in resolving burial disputes poses a challenge when examined from the perspective of legal pluralism. For instance, whereas the judge in Wanjiru [2015] and Omondi (2012) cases argued that a surviving spouse was the closest in proximity to the deceased, followed by his or her children, parents and, finally, relatives, the position of customary law on proximity fundamentally differs across communities in Kenya. Proximity is determined either through ancestral lineage, family ties or marriage (Mbiti 1990). For instance in some communities such as among the Abaluhya of western Kenya, parents are considered to be more proximal to their male children than their spouses. Other communities consider the deceased to be more proximal to their ancestors than to the living, a logic that explains the strictness with regard to burial on ancestral land (J aja 2013). Yet in other customs, the doctrine of proximity is largely irrelevant in burial disputes. For instance, whereas a jadak ${ }^{10}$ in certain Luo clans would have children and a spouse, his place of burial upon death is determined by the host family and not by his children (Cotran and Rubin 1970). Similarly, in Luhya and Luo customs, the body of a woman who undertakes statutory marriage but fails to fulfil the customary requirement of having her bride price paid by the husband is returned to her parents' home for burial upon death, regardless of how long she had stayed with the husband (Gunga 2009, 173). Because the taking away of a wife's body is considered as a social disgrace, most men who lose their wives before paying bride price opt to do the same before burial as a way of gaining a right to bury the deceased (Ibid.). This is because although the state recognizes civil marriages, most communities require that the same must be characterised by customary procedures such as payment of bride price. Failure to pay bride price would mean that the marriage would not be customarily recognised notwithstanding its statutory recognition. This reality has complicated matters for bride price abolitionists. Since inheritance of ancestral land is based upon a customary recognition of marriage, women who opt for civil marriages without first undergoing the customary marriage requirements often find themselves at a disadvantage upon the death of their spouses as they are rarely recognised as wives in the eyes of community . This lack of recognition often means that they cannot inherit the deceased husband's ancestral land. The same applies in cases where a couple that underwent a civil marriage but whose only property is ancestral land opts to divorce. Since the Matrimonial Property Act (2013) doesn't consider ancestral land to be matrimonial property, women in such marriages often end up empty handed in the event of a divorce (Matrimonial Property Act 2013, section 6). They cannot seek justice from informal justice systems since these institutions would require proof of bride price, in addition to (or in lieu of) any other statutory requirement on marriages.

The dilemma over the status of customary law is not unique to Kenya. In a landmark ruling, the Supreme Court of Uganda recently declared that the payment of bride price (and the return of the same upon divorce) is unconstitutional as it entrenches gender inequality and the oppression of women (Mifumi (U) Ltd. \& Anor v AG [2015]). This ruling is however problematic because it leaves women in customary marriages

${ }^{10}$ A non-family member who is given land and hosted by the family. 
without any form of customary recognition or protection. In the absence of such a recognition, their status is diminished and inheritance rights compromised in the event of their husband's death.

Formal justice systems, with their narrow interpretation of customary law are largely unsuitable for resolving burial disputes. This is because the doctrines and principles applied in these systems do not recognize the fluidity, dynamism and progressiveness of customary law (Mbote 2002, Kamau 2009, 2015). The call by scholars like Simon Ngare (2006) and Jacob Mwendwa (2017) for the enactment of a unified statute to regulate burial disputes, although very noble, would only trivialise the burial disputes and compromise their resolution. This is because death and burial are not only culture specific but are also subject to ideological and religious diversity all of which would make a unified statute impractical (Nwabueze 2008). One way of navigating through this challenge is to strengthen traditional justice systems in line with article 159 of the Kenyan Constitution which obliges the state to promote the use of traditional justice systems in dispute resolution. This will not only ensure that burial disputes are addressed in a timely manner but will also save time and resources that are spent addressing these disputes through the Courts. This approach has been quite successful in the resolution of disputes over community land (Kariuki and Kariuki 2015). In fact the Community Land Act (2016) makes it mandatory for parties to seek the intervention of informal justice systems before opting to go to court (Community Land Act 2016, Section 39).

The use of informal justice systems in dispute resolutions is increasingly becoming so entrenched that courts are even embracing their decisions in criminal cases. For instance in R $\vee$ Benard Kiptoo Langat et al [2014], the court put Benard Langat and his two accomplices (who had been accused of murder - that was later reduced of manslaughter), on probation on ground that the case had already been resolved through the village elders. As stipulated by Kipsigis culture, Langat and his coaccused paid compensation in form of cattle to the victim's family and underwent a cleansing ceremony. Similarly, in R v Mohamed [2013], the accused, who had been charged with murder, was set free on the basis that the two families had reconciled in an informal justice process presided over by Somali elders in line with Somali culture.

Although the Constitution, the Judicature Act (1967), the Succession Act (1981), the National Land Commission Act (2012), the Marriage Act (2014) and the Magistrates Court Act (2015) all recognize customary law and traditional dispute resolution mechanisms, the state has done very little regard to promoting the use of these institutions. Key players in the legal systems including the former Chief Justice have encouraged the state to respond to its legal obligation and strengthen these systems but to date not much has been done in this respect. In his speech to Cohesion goodwill ambassadors, Dr. Mutunga, the former Chief justice, observed that:

\begin{abstract}
... the Constitution requires the Judiciary to promote alternative forms of dispute resolution, among them reconciliation, mediation, arbitration and traditional dispute resolution mechanisms (...). Judicial officers are required to embrace the principle of alternative dispute resolution in their daily work, but they do not have a monopoly on its use (...). I encourage Kenyans to use family forums, places of worship and traditional settings to resolve their issues away from adversarial and costly court processes. ${ }^{11}$
\end{abstract}

As highlighted by Dr. Mutunga, parties in burial disputes should be encouraged by the state to try out traditional dispute resolution procedures before going to court. The matters would (where necessary) end up in courts, not as issues of original jurisdiction as is the case currently, but as appeals from the traditional dispute resolution mechanisms such as chiefs and councils of elders. The state can do this by

11 Willy Mutunga, Remarks by the chief justice, at the induction retreat for Cohesion and Integration Goodwill Ambassadors, 29 August 2010 at Crowne Plaza Hotel, Nairobi. Available with the author. 
enhancing the socio-political and legal space through which these systems operate as well as by encouraging disputants to embrace them in addressing burial disputes. This is because unlike state law, customary law has social, psychological and cultural validity (Onyango 2013). Its development is neither anchored on any legal reform nor on classical western jurisprudence but simply on evolving cultures and patterns of human behavior. To this end, the methodological approaches of the formal justice systems are generally unsuitable in interpreting customary law whose success and enforcement in dispute resolution is not based on state coercion but on moral, psychological and social-cultural validity (I bid.). As noted by Roscoe Pound (cited in Nelken 2008), the value of a law and legal system doesn't lie in its origin or structure but on its instrumental ability to contribute to social engineering through the resolution of societal conflicts and controlling of social behavior. This can best be achieved by addressing matters of customary law through customary dispute resolution structures.

\section{Conclusion}

Most post-colonial societies are largely at crossroads with regards to the place of customary law in their jurisdictions (Ubink and van Rooij 2011, 7). Whereas countries like South Africa, Nigeria and Ghana have promoted the use of customary law by establishing traditional courts, Kenyan government has largely given lip service to this area of law. Instead it has embraced a hybrid system in which both customary law and state law are subject to interpretation by state courts. As noted earlier, this has posed a jurisprudential and practical challenge that has put into question the ability of the courts to adjudicate in customary matters.

Legal pluralism, with its recognition of multiple legal systems therefore offers a conceptual framework through which the state can unpack this problem as it provides for a variety of dispute resolution systems which can complement each other to amicably resolve the question of burial disputes in Kenya. To this end, the paper argues that the most practical way of addressing burial disputes is to closely work with traditional justice systems. This will cure the underlying challenge of applying common law principles to customary law matters, a reality which has not only resulted in absurd legal outcomes in burial disputes but also protracted and highly contested legal outcomes.

Compared to state courts, traditional justice systems resolve disputes on a case by case basis. Although there are general customary principles that underpin each disputes traditional dispute resolution systems general blend various option that would result into the most restorative outcome. Such an approach, if well utilized, can be used to enhance the effective resolution of burial disputes.

\section{References}

Abdullahi, A.M., 1999. Burial Disputes in Modern Kenya: Customary Law in a Judicial Conundrum. University of Nairobi Press.

An-Na'im, A.A., 1992. Towards a Cross Cultural Approach to Defining International Standards of Human Rights: The Meaning of Cruel and Inhuman or Degrading Treatment or Punishment. In: A.A. An-Na'im, ed., Human Rights in Cross Cultural Perspectives: a Quest for Consensus. Philadelphia: University of Pennsylvania Press.

An-Na'im, A.A., 2010. The Compatibility Dialectic: Mediating the Legitimate Coexistence of Islamic Law and State Law. Modern Law Review, 73 (1), 1-29.

Bennett, T.W., 1991. A sourcebook of African customary law for Southern Africa. Cape Town: Juta.

Bennett, T.W., 2009. Re-Introducing African Customary Law to the South African Legal System. The American J ournal of Comparative Law, 57 (1), 1-31. 
Bennett, T.W., 2011. Ubuntu: An African Equity. Potchefstroom Electronic J ournal [online], (14) 4, 30-61. Available from:

https://www.ajol.info/index.php/pelj/article/download/68745/56815 [Accessed 19 April 2018].

Brennan, M., 2008. Mourning and Disaster: Finding Meaning in the Mourning for Hillsborough and Diana. Newcastle-upon-Tyne: Cambridge Scholars.

Chanock, M., 1989. Neither Customary nor Legal: African Customary Law in an Era of Family Law Reform. International J ournal of Law and the Family, 3, 72-88.

Chopra, T., and Isser, D., 2011. Women's Access to Justice, Legal Pluralism and Fragile States. In: P. Albrecht et al., eds., Perspectives on Involving Non-State and Customary Actors in J ustice and Security Reform [online]. Rome: International Development Law Organization in conjunction with the Danish Institute for International Studies. Available from: http://pure.diis.dk/ws/files/61420/DIIS_Book.pdf [Accessed 9 April 2018].

Cotran, E., and Rubin, N.N., eds., 1970. Readings in African law. London: F. Cass.

Davies, J.A., and Dagbanja, D.N., 2009. The Role and Future of Customary Tort Law in Ghana: a Cross-Cultural Perspective. Arizona J ournal of International \& Comparative Law [online], 26 (2), 303-333. Available from: http://arizonajournal.org/wp-content/uploads/2015/10/DaviesDagbanja.pdf [Accessed 10 April 2018].

De Mot, J.P.B., and Parisi, F., 2014. Customary Law. In: M.T. Gibbons, ed., The Encyclopedia of Political Thought. Hoboken, NJ: Wiley-Blackwell, pp. 792-793.

Ehrlich, E., and Isaacs, N., 1922. The sociology of law. Harvard Law Review, 36 (2), 130- 145 .

Ellickson, R.C., 2005. Order without Law: How Neighbors Settle Disputes. Rev. ed. Cambridge, MA: Harvard University Press.

Fuller, L.L., 1964. The Morality of Law. New Haven, CT / London: Yale University Press.

Fuller, L.L., 1969. Human Interaction and the Law. The American J ournal of J urisprudence [online], 14 (1), 1-36. Available from: https://academic.oup.com/ajj/article-pdf/14/1/1/7289948/ajj-14-1.pdf [Accessed 10 April 2018].

Griffiths, J., 1986. What is Legal Pluralism? The Journal of Legal Pluralism and Unofficial Law, 18 (24), 1-55.

Gunga, S.O., 2009. The politics of Widowhood and Re-Marriage among the Luo of Kenya. Thought and Practice: a Journal of the Philosophical Association of Kenya [online], 1 (1), 165-178. Available from: https://pdfs.semanticscholar.org/fafb/6ab796944718e1d7c653e239ded2ce9b 44a0.pdf [Accessed 10 April 2018].

Gyekye, K., 1996. African Cultural Values: An Introduction. Lansing, MI: Sankofa.

Hart, H.L.A., 1961. The Concept of Law. Oxford: Clarendon Press.

Jackson, S.A., 2006. Legal Pluralism between Islam and the Nation-State: Romantic Medievalism or Pragmatic Modernity? Fordham International Law J ournal [online], 30 (1), 158-176. Available from: https://ir.lawnet.fordham.edu/ilj/vol30/iss1/5 [Accessed 10 April 2018].

Jaja, J.M., 2013. The Dead in the Lives of the Living: A Socio-Cultural Survey of Burial Sites in the Niger Delta. Global J ournal of Human-Social Science Research [online], 13 (3). Available from: 
https://socialscienceresearch.org/index.php/GJHSS/article/view/907/0 on 5/8/2017 [Accessed 10 April 2018].

Jupp, P.G., and Gittings, C., eds., 2000. Death in England: an Illustrated History. New Brunswick, NJ: Rutgers University Press.

Kamau, W., 2009. Law, Pluralism and the Family in Kenya: Beyond Bifurcation of Formal Law and Custom. International Journal of Law, Policy and the Family [online], 23 (2), 133-144. Available from: https://ssrn.com/abstract=1401797 [Accessed 10 April 2018].

Kamau, W., 2015. Judicial Approaches to the Applicability of Customary Law to Succession Disputes in in Kenya. East African Law Journal, 1 (1), 140-164.

Kariuki, F., 2015a. Community, Customary and Informal Justice Systems in Kenya: Reflecting on and Exploring the Appropriate Terminology [online]. Nairobi: Strathmore University Dispute Resolution Centre. Available from: http://www. strathmore.edu/sdrc/uploads/documents/books-andarticles/Paper\% 20on\% 20Traditional\% 20justice\% 20terminology.pdf [Accessed 18 April 2018]

Kariuki, F., 2015b. Conflict Resolution by Elders in Africa: Successes, Challenges and Opportunities. Alternative Dispute Resolution, 3 (2), 30-53.

Kariuki, M., 2015. Empowering Kenyan People through Alternative Dispute Resolution. Alternative Dispute Resolution, 3 (2), 64-108.

Kariuki, M., and Kariuki, F., 2015. ADR, Access to J ustice and Development in Kenya. Strathmore University Law J ournal [online], 1 (1), 1-25. Available from: http://www. strathmore. edu/sdrc/uploads/documents/books-andarticles/ADR\% 20access\% 20to\% 20justice\%20and\%20development\%20in\% 20 Kenya.pdf [Accessed 10 April 2018].

Kuzenski, W., 1924. Property in Dead Bodies. Marquette Law Review [online], 9 (1), 17-24. Available from:

http://scholarship.law.marquette.edu/mulr/vol9/iss1/3 [Accessed 10 April 2018].

Lagoutte, S., ed., 2014. Dissolution of Marriage, Legal Pluralism and women's rights in Francophone West Africa [online]. Bamako / Dakar / Niamey / Copenhagen: Danish Institute of Human Rights. Available from:

https://www. humanrights. dk/files/media/billeder/nyheder/engelsk_version.pd f. [Accessed 10 April 2018].

Letsas, G., 2012. Harmonic Law: The Case against Pluralism. In: J. Dickson and P. Eleftheriadis, eds., Philosophical Foundations of European Union Law. Oxford University Press.

Levi, E.H., 1948. An Introduction to Legal Reasoning. University of Chicago Law Review [online], 15 (3), 501-574. Available from:

https://chicagounbound.uchicago.edu/cgi/viewcontent.cgi?referer=https://ww w.google.es/\&httpsredir $=1 \&$ article $=5687 \&$ context=journal_articles [Accessed 10 April 2018].

Mamdani, M., 1996. Citizen and Subject: Contemporary Africa and the Legacy of Late Colonialism. $1^{\text {st }}$ ed. New J ersey: Princeton University Press.

Mbiti, J.S., 1990. Introduction to African Religion and Philosophy. $1^{\text {st }}$ ed. Oxford: Heinemann.

Mbote, P.K., 2002. Gender Dimensions of Law, Colonialism and Inheritance in East Africa: Kenya Women's Experience [online]. Originally published in Verfassung und Recht in Übersee, 35/3. Republished by International Environmental Law 
Research Centre, Geneva. Available from:

http://www. ielrc.org/content/a0205.pdf [Accessed 10 April 2018].

Michaels, R., 2005. The Re-state-ment of Non-State Law: The State, Choice of Law and the Challenge from Global Legal Pluralism. Wayne Law Review [online], 51, 1210-1254. Available from: https://scholarship.law.duke.edu/faculty_scholarship/1226/ [Accessed 10 April 2018].

Moore, S.F., 1973. Law and Social Change: the Semi-autonomous Social Field as an Appropriate Subject of Study. Law and Society Review [online], 719-746. Available from: http://www.jstor.org/stable/3052967 [Accessed 18 April 2018].

Musembi, C.N., 2003. Review of Experience in Engaging with 'Non-state' J ustice Systems in East Africa [online]. Institute of Development Studies, Sussex University. DFID funded research paper, 23. Published by: Governance and Social Development Resource Centre. Available from: http://www.gsdrc.org/docs/open/ds37.pdf [Accessed 10 April 2018].

Mwendwa Malelu, J., 2017. The Need for Disposal of Dead Body Legislation in Kenya. Kenya Law Reform Commission Blog [online], 19 February. Available from: http://www.klrc.go.ke/index.php/klrc-blog/511-concept-paper-on-needfor-disposal-of-dead-body-legislation-in-kenya?showall=1 [Accessed 10 April 2018].

Mwimali, B.J., 2015. Human Rights Perspective of Informal Dispute Resolution Processes and the Criminal Justice System in Kenya. Law Society of Kenya Journal, 2 (2) 1-11.

Ndulo, M., 2011. African Customary Law, Customs and Women's Rights. Indiana Journal of Global Legal Studies [online], 18 (1), 87-120. Available from: https://www. repository. law.indiana.edu/ijgls/vol18/iss1/5 [Accessed 18 April 2018].

Nelken, D., 2008. Eugen Ehrlich, Living Law, and Plural Legalities. Theoretical Inquiries in Law [online], 9 (2), 444-469. Available from: https://www7.tau.ac.il/ojs/index.php/til/article/download/691/650 [Accessed 10 April 2018].

Ngare, S.N., 2006. Burial Disputes in Kenya: A case for Legislation. Thesis for the Master's of Laws Degree. University of Nairobi Research Archive.

Nwabueze, R.N., 2008. Legal Approaches to the Burial Rights of a Surviving Wife. Amicus Curiae [online], 73, 12-15. Available from: http://sasspace.sas.ac.uk/1722/1/Amicus_Curiae_2008_Issue_73\%2C_12-15.pdf [Accessed 10 April 2018].

Nyamu, C.I., 2000 .Achieving Gender Equality in Plural Legal Context: Customs and Women's Access to Control of Land in Kenya. Third World Legal Studies [online], 15 (1), 21-63. Available from:

http://scholar.valpo.edu/twls/vol15/iss1/3 [Accessed 10 April 2018].

Ojwang, D., 2015. Dismantling J urist Stereotypes towards the Traditional J ustice Systems: Can Something Good come from Article 159 (2) (C) of the Constitution? Alternative Dispute Resolution, 3 (2), 192-204.

Onyango, P., 2013. African Customary Law: An Introduction. Nairobi: Law Africa.

Oomen, B., 2014. The application of socio-legal theories of legal pluralism to understanding the implementation and integration of human rights law European J ournal of Human Rights [online], 4, 471-495. Available from: https://ssrn.com/abstract=2919353 [Accessed 19 April 2018]. 
Pavone, T., 2014. A Critical Adjudication of the Fuller-Hart Debate [online]. Available from:

https://scholar.princeton.edu/sites/default/files/tpavone/files/fullerhart_debate_critical_review.pdf [Accessed 10 April 2018].

Pimentel, D., 2010. Legal Pluralism in Post-Colonial Africa: Linking Statutory and Customary Adjudication in Mozambique. Yale Human Rights and Development Law J ournal [online], 14 (1), Article 2, 59-102. Available from https://pdfs. semanticscholar.org/5f99/6354ded978218afbeecb2367c2476962 b58a.pdf [Accessed 18 April 2018].

Scharffs, B.G., 2004. The Character of Legal Reasoning. Washington and Lee Law Review [online], 61, 733-786. Available from:

http://law2.wlu.edu/deptimages/Law\%20Review/61-2Scharffs.pdf [Accessed 10 April 2018].

Tamanaha, B.Z., 2008. Understanding Legal Pluralism: Past to Present, Local to Global. Sydney Law Review [online], 30 (3), 375-411. Available from: http://www.austlii.edu.au/au/journals/SydLRev/2008/20.pdf [Accessed 10 April 2018].

Ubink, J., 2011. Stating the Customary: an Innovative Approach to the Locally Legitimate Recording of Customary Law in Namibia. In: J. Ubink and T. Mclnerney, eds., Customary Justice: Perspectives on Legal Empowerment [online]. Rome: IDLO. Available from:

https://www. files.ethz.ch/isn/142874/Customary] ustice3.pdf [Accessed 10 April 2018].

Ubink, J., and van Rooij, B., 2011. Towards Customary Legal Empowerment: an Introduction. In: J. Ubink and T. Mcl nerney, eds., Customary Justice:

Perspectives on Legal Empowerment [online]. Rome: IDLO. Available from: https://www. files.ethz.ch/isn/142874/Customary] ustice3.pdf [Accessed 10 April 2018].

Waldron, J., 2008. No Barking: Legal Pluralism and the Contrast between Hart's J urisprudence and Fuller's [online]. For the colloquium: The Hart-Fuller Debate 50 Years On. Acton: Australian National University College of Law, 17-19 December. Available from: https://law.anu.edu.au/sites/all/files/waldron.pdf [Accessed 10 April 2018].

Woodman, G.R., 1996. Legal pluralism and the search for justice: studying people's search for justice. Journal of African Law [online], 40 (2), 152-167. Available from: https://www.cambridge.org/core/journals/journal-of-africanlaw/article/legal-pluralism-and-the-search-forjustice/OA20E0E04EFCA2611565297CF146C093 [Accessed 10 April 2018].

Young, M., and Cullen, L., 1996. A Good Death: Conversations with East Londoners. London: Routledge.

Legal sources

Children Act, No. 8 of 2001. Revised Edition 2016 [2012]. Article 76 (3)(g) [online]. Nairobi: National Council for Law Reporting with the Authority of the AttorneyGeneral. Available from: https://tinyurl.com/ycpw9pl7, C 15-37. [Accessed 9 April 2018].

Constitution of Kenya, 2010 [online]. Available from: http://www. kenyalaw. org/lex/actview.xql?actid=Const2010 [Accessed 9 April 2018].

Judicature Act, No. 16 of 1967 [online]. Nairobi: National Council for Law Reporting with the Authority of the Attorney-General. Available from:

http://kenyalaw.org/lex/rest/db/kenyalex/Kenya/Legislation/English/Acts\% 20 
and\%20Regulations///Judicature\% 20Act\% 20Cap.\% 208\% 20-

\%20No.\%2016\%20of\% 201967/docs/] udicatureAct16of1967.pdf [Accessed 9 April 2018].

Land Act, No. 6 of 2012 [online]. Nairobi: National Council for Law reporting with the Authority of the Attorney-General. Available from:

http://www.parliament.go.ke/sites/default/files/2017-05/LandAct2012.pdf [Accessed 9 April 2018].

Law of Succession Act (1981) Revised Edition 2015 [2012] [online]. Published by the National Council for Law Reporting with the Authority of the AttorneyGeneral. Available from:

http://www.kenyalaw.org/lex/rest/db/kenyalex/Kenya/Legislation/English/Act s\% 20and\%20Regulations/L/Law\% 20of\% 20Succession\% 20Act\% 20Cap. \% 2016 0\% 20-\%20No.\% 2014\% 20of\% 201972/docs/LawofSuccessionAct14of1972.pdf [Accessed 11 April 2018].

Marriage Act, 2014. Kenya Gazette Supplement [online], 62 (Acts No. 4). Nairobi, 6 May. Available from:

http://kenyalaw.org/kl/fileadmin/pdfdownloads/Acts/TheMarriage_Act2014.pd f [Accessed 9 April 2018].

Matrimonial Property Act, No. 49 of 2013 [online]. Nairobi: National Council for Law reporting with the Authority of the Attorney-General. Available from: https://www.ilo.org/dyn/natlex/docs/ELECTRONIC/97351/115471/F540095358/KEN97351.pdf [Accessed 9 April 2018].

Case Law

Alexkor Ltd and Another v Richtersveld Community [2003] ZACC 18 [online]. Available from: http://www. saflii.org/za/cases/ZACC/2003/18.html [Accessed 11 April 2018].

CBG v JLW [2017] eKLR [online]. Available from: http://kenyalaw.org/caselaw/cases/view/142050/ [Accessed 11 April 2018].

Charles Onyango Oduke $\&$ another v Samuel Onindo Wambi [2010] eKLR [online]. Available from: http://kenyalaw.org/Downloads_FreeCases/73816.pdf [Accessed 11 April 2018].

Dobson and Dobson v North Tyneside Health Authority and Newcastle Health Authority [1997] 1 WLR 596 [online]. Available from:

http://iclr.co.uk/document/1991001187/casereport_24934/html [Accessed 11 April 2018].

Edwin Otieno Ombajo v Martin Odera Okumu [1996] eKLR [online]. Available from: http://kenyalaw.org/caselaw/cases/view/29401/ [Accessed 11 April 2018].

Eunice Moraa Mabeche and Another v Grace Akinyi (High Court civil case No. 2777 of 1994).

Frank Angatia v Chrisantus Lubembe [2016] eKLR [online]. Available from: http://kenyalaw.org/caselaw/cases/view/126058/ [Accessed 11 April 2018].

Jacob Blasto Okumu \& 4 Others v Claris Auma [2014] eKLR [online]. Available from: http://kenyalaw.org/caselaw/cases/view/94595/ [Accessed 11 April 2018].

James Apeli and Enoka Olasi v Prisca Buluka (Civil Appeal No. 12 of 1979).

J ohn Omondi Oleng and another v Sueflan Radal (2012) eKLR.

Kandie $\& 2$ others v Beatrice Jepkemoi Cherogony [2002] eKLR [online]. Available from: http://kenyalaw.org/caselaw/cases/view/10244/ [Accessed 11 April 2018]. 
Katet Nchoe and Nalangu Sekut v Republic [2011] eKLR [online]. Available from: http://kenyalaw.org/caselaw/cases/view/74018/ [Accessed 11 April 2018].

Kimani v Gikanga [1965] EA 735.

Maria Gisege Angoi v Macella Nyomenda (Civil Appeal No. 1 of 1981).

Martha Wanjiru Kimata \& another v Dorcas Wanjiru \& another [2015] eKLR [online]. Available from: http://kenyalaw.org/caselaw/cases/view/106319/ [Accessed 11 April 2018].

Mifumi (U) Ltd \& Another Vs Attorney General \& Another [2015] UGSC 13_6 [online]. Available from: https://ulii.org/ug/judgment/supreme-court̄/2015/13 [Accessed 11 April 2018].

Mojekwu \& others v Ejikeme \& others (2000) 5 NWLR 402 [online]. Available from: http://www. equalrightstrust. org/ertdocumentbank/Mojekwu\% 20\&\%20others \% 20v\%20Ejikeme\% 20\&\%20others\%20_2000_\%205\%20NWLR\% 20402.pdf [Accessed 10 April 2018].

Nyariba Nyankomba v Mary Bonareri Munge (2010) eKLR.

Pauline Ndete Kinyota Maingi v Rael Kinyota Maingi (Civil Appeal No. 66 of 1984).

Republic $v$ Benard Kiptoo Langat and 2 others [2014] eKLR [online]. Available from: http://kenyalaw.org/caselaw/cases/view/99603/ [Accessed 11 April 2018].

Republic v Mohamed Abdow Mohamed [2013] eKLR [online]. Available from: http://kenyalaw.org/caselaw/cases/view/88947/ [Accessed 11 April 2018].

Ruth Wanjiru Njoroge v Jemimah Njeri Njoroge \& another [2004] eKLR [online]. Available from: http://kenyalaw.org/caselaw/cases/view/11425/ [Accessed 11 April 2018].

Salina Soote Rotich vs Caroline Cheptoo \& 2 Others [2010] eKLR [online]. Available from: http://kenyalaw.org/caselaw/cases/view/71328/ [Accessed 11 April 2018].

Virginia Edith Wambui Otieno v J oash Ochieng Ougo \& another [1987] eKLR [online]. Available from:

http://kenyalaw.org/caselaw/cases/view/19162//6/2/2017 [Accessed 11 April 2018].

William v William [1882] 20 ChD 659. 